\title{
Probing linguistic change in Arabic vernaculars: A sociohistorical perspective
}

\begin{tabular}{|r|l|}
\hline Journal: & Language in Society \\
\hline Manuscript ID & LSY-A-19-096.R3 \\
\hline Keywords: & Language change, Arabic, Historical sociolinguistics \\
\hline & $\begin{array}{l}\text { It is received wisdom in variationist sociolinguistics that linguistic and } \\
\text { social factors go hand in hand in structuring variability in language and } \\
\text { any consequent instances of language change. We address the } \\
\text { complexity of such factors by exploring data from several Arabic dialects } \\
\text { in the eastern Arab World. We demonstrate that language change does } \\
\text { not always follow expected phonological trajectories, even in cases } \\
\text { where older changes are reconstructed to have operated along so-called } \\
\text { universal patterns. In our explanation of recent changes in these } \\
\text { dialects, we emphasise the role of social motivations for language } \\
\text { change and the interactions between these social constraints and purely } \\
\text { linguistic ones. Our analysis of change is supported by historical } \\
\text { accounts of variation and change in Arabic. We illustrate how general } \\
\text { principles of sociolinguistic theory apply to the Arabic data and provide } \\
\text { additional layers of sociolinguistic information that highlight the } \\
\text { importance of diverse data for evaluating cross-linguistic generalisations. }\end{array}$ \\
\hline Abstractions \\
\hline
\end{tabular}

\section{SCHOLARONE Manuscripts}


Probing linguistic change in Arabic vernaculars: A sociohistorical perspective

\author{
Enam Al-Wer, University of Essex \\ enama@essex.ac.uk \\ Uri Horesh, University of Essex \\ urile@me.com
}

Deema AlAmmar, Imam Muhammad Ibn Saud Islamic University

DlAmmar@imamu.edu.sa

\author{
Hind Alaodini, University of Essex \\ hindka3@gmail.com \\ Aziza Al-Essa, King Abdulaziz University \\ aalessa@kau.edu.sa \\ Areej Al-Hawamdeh, Jerash University \\ aj.hawamdeh@jpu.edu.jo
}

Khairia Al-Qahtani, King Khalid University

kalqahtani_2007@hotmail.com

Abeer AB Hussain, King Saud University

abhussain@ksu.edu.sa 


\section{ABSTRACT}

It is received wisdom in variationist sociolinguistics that linguistic and social factors go hand in hand in structuring variability in language and any consequent instances of language change. We address the complexity of such factors by exploring data from several Arabic dialects in the eastern Arab World. We demonstrate that language change does not always follow expected phonological trajectories, even in cases where older changes are reconstructed to have operated along so-called universal patterns. In our explanation of recent changes in these dialects, we emphasise the role of social motivations for language change and the interactions between these social constraints and purely linguistic ones. Our analysis of change is supported by historical accounts of variation and change in Arabic. We illustrate how general principles of sociolinguistic theory apply to the Arabic data and provide additional layers of sociolinguistic information that highlight the importance of diverse data for evaluating cross-linguistic generalisations.

\section{INTRODUCTION}

This article focusses on the interaction between internal and external constraints on linguistic variation and change as reflected in data from Arabic dialects spoken in the Arabian Peninsula and the Levant. These data, collected throughout the last decade, ${ }^{1}$ demonstrate various processes and developments through which we address theoretical points, demonstrating the multiple causes of language change - particularly sound change. 
James Milroy (1993) outlines the position taken within sociolinguistics for explaining language change, namely that a combination of language-internal factors and factors external to language itself, essentially social and stylistic factors, are necessary for such an explanation. This, of course, is at the core of the variationist paradigm, but Milroy finds it useful to stress the importance of social constraints on language change as well as on innovation and structured variation. This is because language change has been an object of linguistic inquiry much longer than variation has. Some historical linguists, whose primary aim is indeed the study of language change, have insisted that all that matters in diachronic processes is language itself, the social aspects being not only irrelevant but also 'superficial' and 'unanalysed' (Lass 1980, as presented in J. Milroy 1993: 219-220). Thomason \& Kaufman (1988: 36), on the other hand, not only recognise the pivotal role played by social factors in processes of language change (particularly contact-induced change), but also accord social factors the power of determining the direction of change. In their words:

...our main goal is to describe and analyze linguistic results of language contact situations, and to correlate these results with certain fairly general kinds of social factors. So, although we argue that social factors are the primary determinants of the linguistic outcome of contact situations, our focus is on systematizing the linguistic facts rather than on the various kinds of social influences.

Furthermore, they acknowledge that sociolinguists and anthropologists may indeed be able to elaborate beyond what they call their 'shallow' social analysis, and that in their discussion on language-induced change, they 'consider, in addition to purely linguistic factors, just one social factor: intensity of contact' (Thomason \& 
Kaufman 1988: 46). Such positions taken by historical linguists are indeed reassuring, especially since much of the evidence we present in this article involves language changes propelled by contact, mostly dialect contact.

Within Arabic historical sociolinguistics, it is Jonathan Owens's work that has integrated social factors into the reconstruction of the history of Arabic. He argues that even the earliest treatises of Arabic grammar, dating back to the 8th century, had sociolinguistic material embedded in them (see e.g. Owens 2001: 421), and that our understanding of the development of Arabic relies heavily on the knowledge we possess of the social reality of its speakers. In his 2006 book, A linguistic history of Arabic, he maintains that 'methodologically it is necessary to distinguish between linguistic and sociolinguistic aspects of Arabic for purposes of interpreting Arabic linguistic history' (Owens 2006: 11). This, for him, does not mean that one component is more important than the other; simply that the two ought to be treated as distinct entities, together forming the basis for understanding how Arabic has evolved. Owens's approach to extralinguistic variables is complex. 'Given enough information on these variables', Owens (2006: 16) argues, 'in some cases it is indeed possible to reconstruct plausible developmental frameworks ... Generally, however, such information is incomplete, at best, and even when it is relatively complete automatic predictions do not follow'. What follows from this is not that social factors are not meaningful, but that they are so meaningful that we need to have a full account of as many social attributes of a speech community as possible at any given time in order to make good use of them in understanding language change. It is precisely the paucity of such extralinguistic information about periods in the past that renders it all the more important to record all available information, both linguistic and extralinguistic, as it occurs. 


\section{OVERVIEW OF THE AVAILABLE DATA}

The range of features we analyse in the research presented here represents several changes in progress in Arabic dialects. These features are listed below (all notations are in IPA).

1. $d z>3$

2. $\mathrm{j}>\mathrm{d} 3$

3. lowering or raising of the feminine ending $(-\mathrm{a} \sim-\mathrm{e})$

4. $\operatorname{ts}$ or $\mathrm{t}>\mathrm{k}$

5. $d z>g$

6. $3^{\mathrm{S}}>ð^{\mathrm{S}}$

This list includes features which have been reported to represent universal tendencies; the historical processes surrounding such features are found not only in Arabic but in other languages as well. One example of this is the lenition, or assibilation, of the affricate /d3/ to a fricative [3], reviewed below. This can also be exemplified by the change of interdental fricatives to dental stops, typical of many urban dialects of Arabic. Other features listed above have been reported not to follow what might be perceived as universal tendencies and thus may appear counterintuitive to the 'natural' progression of sound change, as they represent a type of fortition, rather than lenition. An example of this is the shift from affricate /ts/ and / $\mathrm{k} /$ to velar $[\mathrm{k}]$ and $[\mathrm{g}]$, respectively (see below). These so-called counterintuitive changes will form the main bulk of our analysis. Their apparent lack of congruity with notions such as the Principle 
of Least Effort (see the discussion by Labov 2001: 16-18) is further evidence of the primary role played by social factors.

At this juncture it may be useful to exercise some caution. What constitutes a 'natural' sound change is a somewhat subjective matter. In his discussion of the 'linguistic unpredictability of change', Hock (1986: 638) argues that 'notions such as 'assimilation' and 'weakening' provide only apparent causes for change'. He contends that rather than providing us with the kind of explicit linguistic explanation that would enable us to accurately predict the outcome of change, 'we are dealing with a label, delineating one of many possible and natural changes, with many possible and natural varieties'. Similarly, Campbell (2013: 334-335) tackles the question of what might be conceived of as 'natural, regular, universal aspects of language and language change' relying on what he refers to as 'internal causal factors', which to him are at the heart of such universal, or natural tendencies. Interestingly, Campbell classifies as 'internal' factors that reflect the physiological structure of the human vocal tract, as well as those related to human cognition. 'External' factors, according to Campbell, are those 'outside the structure of language itself and outside the human organism' (326) and include many of the elements typically included in a sociolinguistic analysis. Given the complexity of the understanding of how such alleged 'natural/universal' factors are intertwined with social factors, which in turn lead to putative violations of these crosslinguistic principles, we may be better off abandoning these all-encompassing labels and opt to refer to them in terms of their frequencies in the world's languages, as, e.g., 'commonly or rarely found'. This raises another issue, namely that of estimating such frequencies based on the limited knowledge that each of us has of the linguistic processes actually found in all attested languages. 
J. Milroy (1993: 220), makes the following compelling observation:

If we are interested in how language states can remain stable and how speech communities resist change, we have no alternative but to take account of social factors.

We believe this statement can be further extended to include not just a dichotomy between language change and the resistance of change (leading to stability), but rather a more multifaceted divide, which may include the following:

7. Language change in the direction $\mathrm{X}>\mathrm{Y}$

8. Resistance to (7) leading to stability

9. Resistance to (8) leading to a different change: $\mathrm{X}>\mathrm{Z}$

10. Additional cases similar to (9), e.g., $X>W, X>V$ and so on

If indeed, as Milroy posits, social factors must be taken into account whether language change or the lack thereof are concerned, what follows from our extension of this principle is that social factors are crucial to any discussion where a potential change is involved. And while certain changes may be more likely as they are shared by a good number of related and unrelated languages or dialects, other, seemingly unlikely changes are also possible, and it is the social element that may provide a comprehensive explanation to the prevalence of the actual diachronic outcome, be it linguistically more probable or less so.

Before we delve into the intricacies of the processes we use to illustrate the principles outlined above, it may be useful to provide a schematic view of the changes in our findings. This is presented in Table 1. 
[TABLE 1 HERE]

[FIGURE 1 HERE]

\section{DIFFERENT TRAJECTORIES IN THE DEVELOPMENT OF THE PHONEME /ḑ/}

Diachronically, modern Arabic /d $/$ / is reconstructed to have descended from ProtoSemitic $* g$. In fact, Zaborski (2007: 494-495) argues that is it likely that Proto-Semitic (or at least some 'dialects' thereof) already had palatalised allophones, most likely in the form of $\left[g^{j}\right]$. Other allophones or otherwise non-distinctive variants included $[\mathrm{t}]$ and [d] and in some dialects [3] (Cantineau 1960, Zaborski 2007).

Today, the velar realisation [g] is found in three regions: Egypt (Woidich \& Zack 2009), Yemen (Behnstedt 2016) and Oman (Holes 2001); other realisations include [g $\mathrm{g}^{\mathrm{j}}$, [d], [j], [d] and [3]. In the Maghreb dialects (Morocco, Algeria, Tunisia and Libya), we find both the fricative and affricate variants (see, e.g., Messaoudi 2019).

In the Levant, the fricative is predominant in city dialects (a notable exception is the dialect of Aleppo, which has an affricate), while the affricate is found in the traditional dialects of Ḥōrān (southern Syria and northern Jordan), eastern Syria and other regions in Jordan. Al-Wer (1991) investigated this feature in three Jordanian towns and found the traditional [d] to be undergoing change to [3]. This study, of the speech of women in the provincial towns of Salt, Kerak and Ajloun, where educated speakers, as well as young speakers (aged 18-28), who were more prone to mobility and contact with speakers of the supralocal variety, were found to be more susceptible 
to change in the direction of $d z>3$. Both the most uneducated and the oldest $(61+)$ groups used the incoming [3] only $1 \%$ of the time, whereas the most educated and youngest groups used it at rates of $17 \%$ and $22 \%$, respectively.

Al-Tamimi (2001) and Al-Khatib (1988) reported the same development in the northern Jordanian city of Irbid; Al-Wer's (2007) research on the newly formed dialect in Amman confirms that the fricative variant is being focussed there. These results from both large urban centres and smaller provincial locales in Jordan show that similar patterns can prevail across communities of different characteristics; this is only explainable if we consider the social forces that operate in each community.

In Arabian Peninsula dialects, the glide realisation [j] is found in the Gulf dialects and in the eastern region of Saudi Arabia (where it seems to be recessive, as found by Alaodini 2019). In the rest of the country, the typical realisations of this phoneme include either the affricate or the fricative; generally, the affricate is the usual form in the central and eastern regions, including Riyadh, while the fricative is the typical realisation in Jeddah.

A recent study by Hussain (2017) provides detailed information of variation and change involving this sound in Medina, Saudi Arabia. The study investigates two groups: an urban group (the indigenous population of the city) and a Bedouin group (more recent arrivals affiliated with the Banu Masrūh clan of the Ḥarb tribe). The traditional dialects of both groups have the affricate variant, but are now undergoing change in the direction of the fricative variant. An important difference between these communities is their relationship with the cosmopolitan city of Jeddah, where the fricative variant is the typical realisation of this phoneme, such that the urban community have closer and more intimate connections with Jeddah. The study analysed the variable in relation to 
linguistic and social constraints. The results show that the incoming variant [3] is used in $43 \%$ of the total occurrences of this variable, with the youngest age groups leading the change towards [3]; younger speakers use it at a rate which is significantly higher than older speakers, suggesting that this is a change in progress. As far as gender is concerned, female speakers lead the change. Urban speakers lead the change in comparison to their Bedouin counterparts.

Hussain has also found that linguistic constraints are at play. The incoming variant is favoured following high front vowels (and the glide [j]) and preceding coronals. In terms of syllable structure, it is favoured in coda position and unstressed syllables, and disfavoured in onset and stressed syllables.

In other words, variation in the use of this variable in Medina is structured by age, gender, social group, and a series of linguistic constraints. The linguistic constraints, which include phonological environment and syllable structure, give rise to allophony under the conditions mentioned above. The phonology of the Medina dialect is thus being restructured vis-à-vis this feature, as no such allophony had existed in the traditional dialects of either social group. But this restructuring and the emergence of allophony are intrinsically tied to the social reality in the Medina speech community. The indigenous urban speakers are the ones who tend to have friends and relatives in Jeddah and are generally more mobile and more aligned with that city and the modern aura surrounding it. This is the sector of the community who have direct access to the target feature; they attach positive social values to the incoming form, and act as 'language missionaries', ${ }^{2}$ introducing new linguistic features that they picked up through interacting with members of an outside community in their own locality. The Bedouin group are picking up the feature locally in Medina, through interaction with 
members of the urban group in the workplace, schools, universities and the like. In fact, the Jeddah dialect can be seen as the one becoming the supralocal variety for the western region of Saudi Arabia. By the same token, young speakers, who tend to be more mobile as well, are at the forefront of this phonological change, as are female speakers (which is compatible with findings in most other studies of variation and change in urban dialects worldwide).

Elsewhere in Saudi Arabia, namely in the central and eastern regions, the trajectory of change is in the other direction. Rather than moving away from the affricate $\left[d_{3}\right]$, in these areas it is the target. The main difference is that there is no fricative variant involved. Rather, these dialects have a glide [j] as their traditional variant of this phoneme, similar to the major dialects of the Arabian Gulf, across the eastern border of Saudi Arabia. The change is therefore of the form $\mathrm{j}>\mathrm{d}$. The question that arises is: why does each of these regions within Saudi Arabia have a different variant as its target of change?

Representative of these dialects are those of Al-Ahsa and Dammam. Alaodini (2019) analysed this variable amongst members of the Dawāsir tribe in Dammam. As in the case described above for Medina, Alaodini considered a set of factor groups that included linguistic factors (number of syllables, preceding sound and following sound) and social factors (age, gender and tightness of social network). Factors from both groups were found to be statistically significant in predicting the direction of change and the constraints governing it. The change from [j] to [d] was captured by Alaodini at a very advanced stage, with the youngest group of speakers realising $96 \%$ of the tokens of $/ d 3 /$ in their recorded speech as [d], the middle age group with $78 \%$, and the oldest speakers with $64 \%$. Note that even the oldest speakers have considerably more 
affricates than glides in their speech. As this is an apparent-time study, in which age serves not only as a social category but also as an analytical tool to estimate the state of a sound change over time ${ }^{3}$ it is safe to assume that today's old generation was already rather advanced in abandoning the traditional glide in favour of the affricate variant. Unlike most other studies of this type, male speakers were found to lead this change at $90 \%$ (vs $61 \%$ for female speakers, again, indicating that both gender groups are quite advanced). Finally, loose social networks favour the change (93\%) with tight networks lagging behind at 57\%. These percentages are supported by a fixed-effect logistic regression analysis, ${ }^{4}$ which confirms that all of these results are significant at the $p<0.001$ level, with the social groups that exhibit the highest percentages of [d] also carrying factor weights well above the 0.5 cutting point. $\mathrm{R}^{2}$ is 0.549 , indicating that this statistical model accounts for a good proportion of the variability in the data. The linguistic factors examined, all phonological, confirm that the change is quite advanced, with only one factor, a low-back preceding sound, linked to more [j] (56\%) than [d] (albeit with a very small number of tokens).

In Dammam, young participants (regardless of gender) used the [j] variant consistently only in one lexical item, jadda instead of dzadda 'grandmother'. They were asked why they used [j] rather than [d] in this word in particular. Most of the participants answered that this was the way the word was introduced to them since childhood, so they had got used to addressing their grandmothers with this form. There are indications that their use of [d] is conscious. For instance, they maintain that their parents told them not to use [j] in place of [d]]. Interestingly, they claimed that they did not hear their parents use [j] often, which is inconsistent with the overall level of usage of this variant by the middle age group (22\%). Furthermore, they maintain that [j] is not 
used in their current dialect, but used to be part of a dialect their ancestors spoke when they emigrated from Bahrain. In other words, for them [j] is clearly marked as 'nonSaudi'. Consequently, the preservation of [j] among innovative speakers in the word jadda might be an example of a core dialectal vocabulary that is more resistant to change.

The revelation that parents tell their children not to use [j] is meaningful; it indicates that the parents' generation are or were under pressure to abandon their heritage pronunciation of this sound, which may have marked them as 'outsiders'; in turn, they may have wanted to spare their children unfavourable labelling on the part of the larger community as 'outsiders', 'not real Saudis' and the like. One of the middleaged female participants said that she used to speak differently - in the 'Dammami dialect' - before she went to university. What she meant was that she had used [j], but started to speak differently, especially when she started to study and work. At work she interacted with colleagues who were from different parts of the country, who do not have [j] in their dialects. As a consequence, she started to avoid some of her native linguistic features, so that her dialect would seem neutral and sound like that of others from different dialectal backgrounds. In other words, she was accommodating to the other dialects. Her justification for such linguistic behaviour was that these features were not suitable to be produced in public. The interview with this participant took place after she retired. During the interview the participant did produce some of the local features, such as [j], affricated / $\mathrm{k} /$ and the rounded variant of the long vowel /a:/. Her report of having changed her linguistic behaviour later in life supports Sankoff's assertion that 'individual speakers change over their lifespans in the direction of a change in progress in the rest of the community' (Sankoff 2005:1011). 
If parents tell their children not to use $[j]$ for $/ \mathrm{d} /$, it means that variation in this variable is meaningful, and associated with overt social values. According to Silverstein (2003: 193) the importance of orders of indexicality is that it shows 'how to relate the micro-social to the macro-social frames of analysis of any sociolinguistic phenomenon'. Johnstone, Andrus and Danielson (2006) explain the orders of indexicality according to a study they carried out in Pittsburgh. First-order indexicality is when a linguistic form acquires a sociodemographic character which is only noticeable to experts (i.e.

linguists), and is usually not even noticeable to speakers within the community, until it reaches second-order status. Second-order indexicality is when people are aware of the first-order associations for social reasons, such as for work and identity, or when people become aware that they speak differently, and their speech carries some marked or stigmatised features. Third-order indexicality is when a linguistic variable is explicitly known to both insiders and outsiders as a local feature.

It is important to consider the local social meaning of linguistic variables. If the variable has a negative social meaning it will likely be abandoned by speakers. With this in mind, the fact that the participants in the Dammam study show awareness of the abandonment of features such as [j] means that the variable (dz) can be considered to have second-order indexicality. Eckert \& Labov (2017: 4) summarise the relation of social meaning to diachronic change as follows: 'Like reference, the indexicality of a variable emerges in use and can change over time, along with changes in the social distinctions it picks out'. The Dammam case is a good example of this principle, as the variant [j] denotes different things for different people in different situations and across generations. 
In the Gulf states, where it is [j] that is the most commonly used dialectal variant, and [d] is characteristic of the speech of less-powerful, often marginalised, groups, several studies (e.g., Al-Amadidhi 1985 for Qatar; Taqi 2010 for Kuwait; Holes 1980, 1987 and Al-Qouz 2009 for Bahrain) have found change in progress in the direction of the by-now Gulf-wide norm, [j]. For instance, in Bahrain, where the community comprises two distinctive groups: the Bahạarna Shi'is and the 'Arab Sunnis, who speak genealogically distinct dialects, and who differ in social and political dominance (the 'Arab are the dominant group) - we see the following development of /d3/. Traditionally, the Bahārna group use [d]], while the 'Arab group use [j]. Holes (1980) reports a tendency on the part of the Bahārna group to shift their pronunciation of this phoneme towards [j], which is, for all intents and purposes, the koineised form throughout the Gulf region. Real time data for this community are available through AlQouz's (2009) trend study, which revisited a subset of the community originally sampled by Holes. She found that [j] has become the main variant of the young Bahāana and that their traditional variant $\left[\mathrm{d}_{3}\right]$ is rarely used in daily interactions. ${ }^{5}$

We see therefore that regardless of the phonological trajectory of the change - be it fortition, lenition, assibilation, and so forth - it is always in the direction of the variant used traditionally by the dominant social group. We have seen evidence of this in Jordan and the Arabian Peninsula, where the phoneme / $d /$ was examined at the micro level, considering both linguistic and social factors.

\section{PALATALISATION AND DEPALATALISATION}

Evidence from a vocalic morphophonemic feature: the feminine ending 
In Arabic dialects, there is a suffix that denotes feminine grammatical gender in many nouns and most adjectives. It occurs in both an unbound state, as V\#, and in the construct state ('ịdâfa in Arabic) as Vt. In what follows, we are only concerned with the unbound state, i.e. cases where the noun or adjective in question does not function as a head noun immediately followed by a complement or adjunct noun. The quality of the final vowel designating singular feminine grammatical gender (henceforth 'feminine ending') can be of two types: /a/-type or /e/-type (the latter can also be realized, depending on the specific dialect, as [E], [I] or other non-open front vowels).

In normative Standard Arabic (SA) the suffix in the unbound state is realised as [a]. In some dialects, however, the open vowel /a/ in the feminine ending in the unbound state has a raised variant, namely /e/ (or [E] or [I]), all of which we shall treat as 'raised' variants. Although we do not know the exact triggering environment of the raising of this open vowel in the feminine ending historically, in the modern dialects that raise conditionally, such as the dialects of most cities in the Levant, the environments of a preceding coronal sound and the presence of an /i/-type vowel in the vicinity generally trigger raising. This suggests that historically raising of the feminine ending in Arabic was subject to similar conditions as those that governed the process in other languages.

We are following Bhat (1978) in classifying the fronting of a back vowel or raising of a front vowel as a type of palatalisation. According to Bhat, this is sometimes triggered by a nearby palatal or palatalised consonant, as in the reconstruction of French open vowels raising to [e] or [ $[\varepsilon]$ after a palatalised velar consonant, and Russian /a/ to near open [æ] near palatalised consonants; or it can be triggered by a high front vowel as in the Germanic umlaut. ${ }^{6}$ Additional examples from other languages are 
provided by Bhat (1978: 74-75). Levin (2009: 311), in his discussion of the process known in Arabic as 'imāla - which encompasses both the raising of long medial vowels, e.g. a:>e:, and the raising of the short vowel /a/ in the feminine ending - synthesises the positions of mediaeval grammarians on the 'imāla 'as a phenomenon close to that known today as 'vowel harmony".

In some dialects the historical conditioning factors of raising of the feminine ending completely collapsed, resulting in dialects that raise this ending unconditionally. Such dialects can be found in eastern Arabia and Iraq (Ingham 2009; Abboud 1979).

The situation with respect to the realisation of the feminine ending currently can be summarised in the following way:

11. dialects that do not raise at all, such as the west Arabian dialects (e.g. Jeddah); also Cairo and Gaza (Cotter 2013)

12. dialects that raise in all environments; such dialects are found in east Arabia, for example Šammar of Ḥàil (AlAmmar 2017), and various dialects in the Al-Ahsa region (Al-Bohnayya 2019)

13. dialects that raise, or do not raise, conditionally. Levantine dialects in general fall in this category. These dialects can be subdivided further into two types: in Type 1 the underlying form /a/ is the default choice (Al-Wer 2002) and raising is the derived choice; broadly, the rule is: choose /a/ except after coronal sounds. This is the rule that governs raising in the traditional Jordanian dialects, including the Horāni dialects. In Type 2, the raised variant is the default choice whereas the open variant is the derived choice: choose /e/ except after back sounds, including emphatic and emphaticised consonants. This is the rule found in 
Levantine city dialects in general. Jerusalem (Levin 1994), Jaffa (Cotter \& Horesh 2015), Damascus and Beirut are of this type.

As Al-Wer (2007) has shown in her analysis of the Amman data, the Jordanian dialects are currently undergoing change from Type 1 to Type 2 ; this development can be characterised as a phonological change, which consolidates the status of 'raising' in the system. Where there is change in this feature in the Levant overall, the trajectory of developments seems to be in the direction of conditioned raising, as it is in the Damascus dialect. This development in the region is undoubtedly motivated by the cultural dominance of the 'raising dialects'.

The exact opposite sociolinguistic situation prevails in Saudi Arabia, which is also where the reverse development is taking place, namely lowering namely lowering/depalatalisation of the feminine ending.

AlAmmar's study in Hầ'il found that lowering of the feminine ending to - $a$ is progressing steadily, strongly favoured by the younger generation (FW 0.87), the high contact group (FW 0.83) and women (FW 0.55). ${ }^{7}$ It is interesting to note that lowering is also favoured after the glide $/ \mathrm{j} /$, which is one of the prime environments that motivate raising in other dialects of Arabic and in other languages. The category 'emphatics' phonetically, consonants with a secondary pharyngealised articulation - which is the environment that blocks raising in Levantine dialects, and said to block raising by the mediaeval grammarians, favours raising in Ḥâ'il. This peculiar arrangement of linguistic constraints on lowering in Hă'il suggests that the incoming feature (the open vowel) is as yet not integrated in the system, but that it is used as a borrowing from other dialects, and the mechanism is one of sudden replacement, rather than internally motivated incremental transition. In other words, the change in Ḥâ'il is a typical case of 
'change from above' in Labovian terms (Labov 1990, inter alia). All of the major dialects of Saudi Arabia maintain a low vowel realisation in the feminine ending. The dialects that raise this ending are marginal and represent a numerical minority of speakers. The change in Hầ'il is therefore clearly a case of levelling out of a marked feature.

Evidence from a phonological feature: consonantal palatalisation and depalatalization

\section{Historical evidence}

Deaffrication of the affricates that historically originate from velar stops $/ \mathrm{k} /$ and $/ \mathrm{g} /$ is progressing in a number of dialects. In this section we will first provide a brief background to the palatalisation of Arabic velar stops as a historical process, before we move on to discussing our findings regarding the apparently reverse process currently in progress, namely deaffrication/depalatalisation.

The historical process of palatalisation and affrication of $/ \mathrm{k} /$ is mentioned in many sources, going back to the $8^{\text {th }}$ century. Much of the discussion in the early grammatical works refers specifically to the affrication of $/ \mathrm{k} /$ in the $2^{\text {nd }}$ person oblique feminine enclitic $-k i$ to either $-t$, or $-t$. According to mediaeval grammarians, e.g. Sibawayhi, affrication of the $/ \mathrm{k} /$ in the feminine form - $k i$ was motivated by the need to 'affirm and emphasize' (Owens 2013: 175) the distinction between this form and the masculine form $-k a$.

Holes (1991), on the other hand, considers the historical affrication of / $\mathrm{k} / \mathrm{a}$ natural phonological change, whereby / $\mathrm{k} /$ was fronted and affricated in the environment of front vowels. Regardless of the question of whether the preservation of 
gender distinction was the motivation for affrication, the presence of a front vowel in these instances is consistent with typical cross-linguistic developments of the velar stops in front vowel environments (cf. Bhat 1978, Campbell 2013, Hock \& Joseph 2009).

Contemporary research on depalatalisation ${ }^{8}$ of etymological velar stops suggests that gender distinction has an effect on the change in the opposite direction, $[\mathrm{t}]>[\mathrm{k}]$. The constraints on depalatalisation do not have to be the same constraints that governed the original process of palatalisation. In fact, we would argue that synchronic 20epalatalization is only an apparent reversal of the historical development. In the next section, we present data from contemporary Arabic dialects that are undergoing this opposite process.

2. Evidence from contemporary dialects: consonantal depalatalisation

In the contact situation in Amman, the affricate $/ \mathrm{t} /</ \mathrm{k} /$ is levelled out at a very early stage. ${ }^{9}$ In Amman, we find that affricated /k/, which used to be prevalent in the dialect of those who migrated to Amman from Salt, is almost non-existent in the speech of the first generation (Al-Wer 2007). For this feature to have been levelled out quickly in the Amman context is not at all surprising, given the sociolinguistic situation in Jordan and overall in the Levant, where affrication is a characteristic feature of the dialects spoken by marginalised communities, although by no means a minority feature numerically.

Palatalisation also affects the voiced velar stop /g/ (reflex of Old Arabic ${ }^{*} q$ ) in many of the dialects that palatalise conditionally, such as central and north Najdi. ${ }^{10}$ Clearly, in these dialects, historical palatalisation - in the form of affrication - of velar stops was a systematic development that affected the velar set of consonants, / $\mathrm{k} /$ and 
/g/. Furthermore, affrication of /k/ in these dialects is not confined to the enclitics, but affects $/ \mathrm{k} /$ in the word stem as well. Most dialects that affricate $/ \mathrm{k} /$ in the stem, do so in the environment of front vowels, including /i/ (as is the case in the dialects that affricate the $/ \mathrm{k} /$ in the enclitic -ik), as illustrated in the following examples.

From Sūf, northern Jordan:

14. tfam < kam 'how much'

15. ?astfa $<$ ?aska 'tastier'

16. tannti < kannti 'my daughter in law'

17. te:f < ke:f 'how'

From the speech of Najdis in the city of Jeddah:

18. tse: $f<k e: f$ 'how'

19. $\sin <$ kin 'if'

20. mitsa:n < mika:n 'place'

21.jabtsi <jabki '[he] cries'

22. jatswuin < jakwuin 'they iron'

The data above come from two sociolinguistic investigations: one in northern Jordan (Al-Hawamdeh 2016) and the other in Jeddah (focussing on the behaviour of Najdi speakers living in the city; Al-Essa 2008). Since, as Al-Essa points out, the variation between $[\mathrm{k}]$ and $[\mathrm{ts}]$ in the stem is purely phonological, while variation in the $i k$ enclitic is morphophonemic and carries grammatical information (gender), her study considered /k/ in the stem as a separate variable from /k/ in the enclitic; while these two variables were kept separate, they had the same possible set of variants. Following 
this separation of variables by Al-Essa, Al-Hawamdeh, too, treated variation between [k] and $[\mathrm{t}]$ in the stem separately from variation between the two in the enclitic.

Bearing in mind that Al-Essa's data come from the speech of a minority group within a large urban centre, whereas Al-Hawamdeh's study was conducted in a small, tightly-knit rural community - which explains the difference between the two studies in the retention of the traditional feature - both studies found the same pattern.

Deaffrication in the stem was at an extremely advanced stage of change to $/ \mathrm{k} /$, evinced by the low percentages of the retained affricates ([ts] in Jeddah and [t $]$ in Sūf), whereas in the enclitic the affricate variants remained intact at much higher rates.

\section{[TABLE 2 HERE]}

In the Jeddah study, most speakers did not use [ts] at all (Al-Essa 2008: 138). The $6 \%$ of the affricate tokens reported by Al-Essa all come from four speakers (out of a sample of 61). Two of them, responsible for the main bulk of these tokens, are in the oldest age group; two other speakers in their thirties and forties contributed a small number of tokens as well. According to Al-Essa, this feature is levelled out in the contact situation in Jeddah due to social stigmatisation. The affricate variant [ts] is a hallmark of provincial Najdi localities and is often used to mimic Najdi speakers. There is, therefore, considerable social pressure to abandon this feature when interacting with non-group members.

With respect to the enclitic, we see that the affricate variant is still on its way out, but is used more than three times as frequent as in the stem. According to Al-Essa, the considerably higher level of maintenance of [ts] in the enclitic is connected with its grammatical function as a feature that carries the gender information. 
In Al-Hawamdeh's study, the gap between maintenance of the affricate in the stem and its maintenance in the enclitic is much greater than in Al-Essa's. In Sūf, change in the enclitic is constrained only by social factors. Men were found to be leading the change $(p<0.001)$ and younger speakers (ages 7-50) were at the forefront of the process of deaffrication as well $(p<0.001)$. Although the Sūf situation differs from the Jeddah case in that it does not represent a minority community within a large city, it does share the same experience of certain traditional features being stigmatised. This is because in Jordan, provincial dialects such as that of Süf are under constant pressure to rid themselves of features that would be frowned upon by speakers of the newly formed urban Ammani dialect. While the Sūf speech community remains to a large degree conservative (recall the $70 \%$ of $[\mathrm{t}]$ retention in the enclitic), many of the town's residents travel to and work in nearby Jerash (a prime tourist location), the city of Irbid, and the capital Amman, where certain features of their dialect are often ridiculed.

A further relevant development in the enclitic forms concerns the vowel element. In the Najdi forms, the vowels in the masculine and feminine enclitics are identical, almost a schwa. This aspect of the Najdi system may be thought of as a factor that also inhibits depalatalisation. However, in the Sūf data, gender marking is carried by both the vowel and the consonant, viz. $-i t$ vs $-a k$. These data, therefore, suggest that maintenance of gender distinction may indeed exert influence on the change that these contemporary dialects are undergoing.

In conclusion to this part, the original process of affrication that affected the velar stops in some Arabic varieties was obviously governed by internal constraints, similar to those found in other languages that have undergone affrication of stops. The apparent reversal of this process is clearly constrained by social factors and is sensitive 
to morpheme boundaries. Our studies show that in the reversal of the affrication process, internal constraints probably play a residual role as relics of the original process, but that indeed social pressures are the main motive for the change.

Returning to Al-Essa's study in Jeddah but focussing this time on the correlation of the results for the -ik variant with gender of the speaker, the results show that younger women are the leaders of the change from Najdi -its to Jeddah -ik /-ki. This result corresponds to the gender-differentiated pattern reported in many sociolinguistic investigations of other languages and communities. In the Jeddah case this pattern is mediated through sociocultural differences between men and women among the migrant Najdi community in Jeddah. Al-Essa (2009: 218) explains that:

The use of the feminine suffix seems to be affected by the configuration of the social interaction between men and women in the Najdi community. In a traditional society like the Najdi community social interaction between men and women outside the family sphere is not allowed. Najdi men have limited access to contexts where they would be involved in face-to-face interaction with urban Hijazi ${ }^{11}$ women. We argue that the urban Hijazi suffix -ik is habituated in the speech of Najdi female speakers with the recurrent verbal exchanges in their face-to-face interaction with the urban Hijazi women.

This case presents an interesting paradox in that the gender group who is most severely confined by sociocultural norms, namely the women, is the same group who leads linguistic change away from the norms of the community. In this particular case, which involves a 2 nd person feminine morpheme, this is clearly because the occurrence of the target feature in conversation requires a female addressee. 
Al-Essa's interpretation above draws attention to the importance of factoring in 'opportunity of access to the target feature' and the role of 'sociocultural norms' - here 'segregation' - in our account of the story of language change at the micro level. We shall now look more closely at gender as a social factor, as an extended illustration of the intricate analysis often needed to illuminate sociolinguistic dynamics relevant to language change.

\section{GENDER AS A SOCIAL FACTOR}

Al-Qahtani (2015) studied two isolated villages in Tihāmat Qahțān, in southern Arabia. This area is home to very ancient features, including a lateral fricative realisation of Arabic $/ \mathrm{d}^{\mathrm{S}} /$, viz. $\left[\mathrm{B}^{\mathrm{S}}\right]$, and $m$-as a definite article (versus the majority of Arabic dialects where the article is always $l-$ ). With respect to the emphatic voiced lateral fricative $\left[3^{\complement}\right]$, Al-Qahtani found it to be undergoing a merger with the emphatic voiced interdental [ð`]. In the table, we see the intersection of gender and age regarding the use of the innovative feature $\left[ð^{\complement}\right]$ :

[TABLE 3 HERE]

The figures show that the old female speakers are the most conservative group (vis-à-vis the local traditional dialect), followed by the old male speakers. The gender pattern is reversed in the young group; here, the young female speakers are by far the most innovative group. Noticeably, the young male speakers' usage of the innovative variant, the interdental (27\%), is only slightly higher than the old male speakers' $(20 \%)$. On the other hand, there is a steep increase in the use of the innovative variant from old 
to young female speakers (16\% to $69 \%$ ). In this community, men's economic activities have remained more or less stable, relying for the most part on animal husbandry and honey production. The men are also considerably more mobile than the women since they also trade their products of honey and livestock in the cities of the region. Through this activity, they come into frequent face-to-face interaction with outside communities, and for relatively extended periods of time (days or weeks during each trip). On the other hand, the women are not allowed these opportunities. They cannot travel outside their village independently, either for leisure or to look for work. The lives of women in the village are therefore considerably more constrained and their prospects are extremely limited. For the younger women, the expansion in school and college education in their village and the vicinity meant that they now have the opportunity to spend more years in school and college, which implies longer periods of exposure to outside dialects (spoken by the teachers and students from other localities). This situation is likely to influence or even shape the attitudes of women towards the local community and by extension their attitudes to the local dialects. This is a similar case to the one described by Susan Gal in Oberwart, Austria. In Gal's study (1978) the women were found to be leading language shift from the heritage language (Hungarian) to German, the language that symbolised non-peasant status and non-peasant lifestyle. Gal writes:

For the most recent generation of women peasant life is a much less attractive choice than it is for men. Now that other opportunities are open to these young women, they reject peasant life as a viable alternative. It will be argued here that their language choices are part of this rejection.

(Gal 1978: 11) 
As in Gal's case, in Tihāmat Qahțān as well, women are much more likely to want to seek ways to dissociate from village life, which can be symbolised through divergence from the local norm of speech.

Let us now plunge more deeply into these results by looking at them as the product of social change across generations. The intersection of age and gender in the two generations shows that the gap between women and men in the older generation is very small, while the gap in the younger generation is relatively large. In other words, in the older generation, women and men have a shared norm, while the younger generation show distinct norms based on gender. There is strong evidence based on stories frequently told by older speakers that interaction and communication between the sexes was much freer in their youth than it is today. Consequently, the striking linguistic divergence between the young men and women can be seen as a reflection of social segregation. A further point to note is that the young men largely retain the features of the older generations, and, of the two segregated communities, it is the female group which displays radical innovation.

Evidence of drastic social changes with regard to gendered behaviour is found in field notes by Al-Qahtani from her work in southern Saudi Arabia. One of the women she interviewed spoke about life in the 1970s-1980s.

People were much simpler and more innocent; we all used to sit together, men and women, in the same house telling jokes, eating together, and not a single man would think any woman was behaving disgracefully. When I was young, we used to work together on the farms and help each other and there was no difference between men and women. We would always think of each other as being members of one family, and men of our village would always feel 
responsible to protect us from outsiders. Covering our faces was not common during that time and would be thought of as something new or odd in the community. Weddings were also mixed back then whereby all the guests could have a good time, dance and eat together in the same place. We used to wear our traditional costume which consisted of colourful dresses and yellow headscarves. During and after the 1980s, the social situation dramatically changed after the so-called 'religious awakening' that was dominant across the Kingdom. It was very difficult and awkward for me when I was told by my husband that I could no longer meet with our male friends and neighbours faceto-face as I had done in the past. It just did not feel right to suddenly treat them as strangers. Everything changed: weddings and social gathering became separate; men and women were no longer allowed to sit together in the same place. Contact with men became restricted only to relatives and was very formal.

Our experience conducting fieldwork across the Arab World has provided us with many narratives such as the one quoted above. In provincial Jordanian cities and towns, we have also encountered many such stories, as have additional researchers in other parts of Saudi Arabia (e.g., Lowry, forthcoming). The combination of gendered patterns of linguistic behaviour, as evidenced by micro-sociolinguistic observations, and the macro-level commentaries by speakers regarding the recent introduction of ultraconservative social norms paints a complex picture. It is almost as though segregation between the sexes has allowed the women to innovate unhampered by interaction with a conservative group, the male speakers. We can thus explain the paradox that it is the women who have innovated despite the fact that they have been progressively deprived of the opportunity to develop wider social networks. 


\section{CONCLUSION}

In what is perhaps the foundational text of sociolinguistic theory, Weinreich, Labov \& Herzog (1968) deal with a number of 'problems' or 'riddles', the most difficult of which is the actuation problem (or actuation riddle). Steering the discussion away from the hitherto received wisdom that variation in language can be 'free variation' and that subsequent language change can be 'random', Weinreich et al. (1968: 112) critique earlier accounts of language change, especially that of Hermann Paul (1880). They interpret Paul's approach to language change as one that 'attribute[s] the actuation of a change to chance'. Quite unforgivingly, they argue that 'chance is here invoked illegitimately, since we are out to explain a specific, not a random process'.

Ultimately, this is where the study of language (variation and) change in the social context plays a pivotal role. Decades later, Labov (2001: 466) reminds us that both the beginnings and ends of changes are 'mysterious' or 'difficult to understand'. He proposes to examine this through what he dubs 'the obverse of the actuation problem', namely continuation. In many ways, the case studies in this article capture this stage of continuation; age as a social factor, but also, as we mention earlier, as an analytical instrument for emulating the time depth required to observe a change in progress, has been a common thread in the studies we cite. While some changes are more advanced than others (Alaodini's study of Dammam is a case in point), there is a preponderance of evidence pointing to progression from generation to generation in the rate of use of the innovative forms. Of course, this is not always the case. In other studies carried out recently on Arabic dialects, the role of age as a social factor has been less obvious, compelling researchers to seek alternative or complementary explanations for the 
direction of change. This has been the case in Horesh's (2015) study of the lenition of the voiced pharyngeal fricative / $/$ / in the Palestinian dialect of Jaffa, where age was found to be statistically significant as a predictor of change, but not in the expected order. The youngest age group actually patterned alongside the oldest group in resisting the change, and the middle age group was the one who seemed to be leading it. This peculiarity was resolved (see Cotter \& Horesh 2015: 466-467) by refining the delineation of age groups, separating the youngest young speakers, namely teenagers, from those aged 21-35, and by considering other salient social factors, such as those related to the speakers' contact with and proficiency in Hebrew. In Cotter's study of the variable (q) in Gaza, where it has both voiced velar [g] and glottal [?] variants, Cotter (2016; also see Cotter \& Horesh 2015) has found that while there is 'some indication that age might be a contributing factor' (Cotter \& Horesh 2015: 475), it did not reach statistical significance. What the studies of these Palestinian dialects have in common is the salience of contact - either language contact or dialect contact - as sociolinguistic factors. Whether or not cases of language contact warrant a more complex examination of the social factors involved is left to be seen, but recall that in Al-Essa's study of Najdi speakers in Jeddah, another case of (dialect) contact, the effect of age had to be observed more closely due to the inconsistency of speakers in the middle age group, two of whom exhibited more conservative features than the rest of the group.

It is unlikely that factoring in a speaker's age into the analysis of their speech would have been possible, or even taken seriously, had it not been for the incorporation of social factors in general into the study of language change. That sound change is at all observable had been dismissed as a fallacy by such preeminent linguists as Bloomfield (1933, cited in Labov 1963: 291). It is bold statements like Labov's at the very beginning 
of his study of sound change in Martha's Vineyard, based on novel, yet straightforward methodology, that have opened our eyes to the observability of change. Labov (1963: 273) characterises his own study as 'the direct observation of a sound change in the context of the community life from which it stems'. This is coupled by a later statement from Labov (2001: xv, the foreword to the second volume of his Principles of linguistic change) describing social factors, the focus of the volume, as 'the antecedent conditions that govern and condition the change ... These may involve or affect the speaker's state of mind, and that state of mind may very well bear upon the behavior that implements the change'. We have been able to implement these principles and refine them using data from a variety of Arabic dialects, in the hope that our work will continue to illuminate general questions of language change.

\section{REFERENCES}

Abboud, Peter (1979). The verb in northern Najdi Arabic. Bulletin of the School of Oriental and African studies 42: 647-499.

Al-Amadidhi, Darwish Ghuloom Hussein Yousef (1985). Lexical and sociolinguistic variation in Qatari Arabic. PhD thesis, University of Edinburgh, UK.

AlAmmar, Deema. (2017). Linguistic variation and change in the dialect of Ha'il, Saudi Arabia: Feminine suffixes. PhD thesis, University of Essex, UK.

Alaodini Hind. (2019). A Sociolinguistic study of the Dawāsir dialect in Dammam, Eastern Arabia. PhD thesis, University of Essex, UK. 
Al-Bohnayya, Moayyad (2019). dialect variation and change in eastern Arabia: Al-Ahsa dialect. PhD thesis, University of Essex, UK.

Al-Essa, Aziza (2008). Najdi speakers in Hijaz: A sociolinguistic investigation of dialect contact in Jeddah. PhD thesis, University of Essex, UK.

Al-Essa, Aziza (2009). When Najd meets Hijaz: Dialect contact in Jeddah. In Enam AlWer \& Rudolf de Jong (eds.). Arabic dialectology: In honour of Clive Holes on the occasion of his sixtieth birthday. Leiden: Brill. 203-222.

Al-Hawamdeh, Areej (2016). A sociolinguistic investigation of two Hōrāni features in Sūf, Jordan. PhD thesis, University of Essex, UK.

Al-Khatib, Mahmoud Abed Ahmed (1988). Sociolinguistic change in an expanding urban context: A case study of Irbid city. PhD thesis, University of Durham, UK.

Al-Qahtani, Khairiah (2015). A sociolinguistic study of the Tihami Qahtani dialect in Asir, Southern Arabia. PhD thesis, University of Essex, UK.

Al-Qouz, Muna (2009). Dialect contact, acquisition and change among Manama youth, Bahrain. PhD thesis, University of Newcastle, UK.

Al-Tamimi, Feda' YousefAli (2001), Phonetic and phonological variation in the speech of rural migrants in a Jordanian city. PhD thesis, University of Leeds, UK.

Al-Wer, Enam (1991). Phonological variation in the speech of women from three urban areas in Jordan. PhD thesis, University of Essex, UK. 
Al-Wer, Enam (2002). Jordanian and Palestinian dialects in contact: Vowel raising in Amman. In Mari Jones \& Edith Esch (eds.), Language change: The interplay of internal, external and extra-linguistic factors. Berlin: Mouton de Gruyter. 63-79.

Al-Wer, Enam (2007). The Formation of the dialect of Amman. In Catherine Miller, Enam Al-Wer, Dominique Caubet and Janet Watson (eds.). Arabic in the city: Issues in dialect contact and language variation. London: Routledge. 55-76.

Barkat-Defradas, Melissa (2009). Vowel backing \& vowel lowering in Arabic vernaculars. In Kees Versteegh et al. (eds.) Encyclopedia of Arabic Language and Linguistics. Leiden: Brill. Online edition.

Behnstedt, Peter (2016). Dialect atlas of North Yemen and adjacent areas. Handbuch des Orients 114. Leiden: Brill.

Bhat, Darbhe N. S. (1978). A general study of palatalization. In: Joseph H. Greenberg (ed.). Universals of human language, Vol. 2: Phonology. Stanford: Stanford University Press. 47-92.

Bloomfield, Leonard (1933). Language. Repr. 1984. Chicago: University of Chicago Press.

Campbell, Lyle (2013). Historical linguistics: An introduction. Edinburgh: Edinburgh University Press.

Cantineau, Jean (1960). Étude de Linguistique Arabe. Paris: C. Klincksieck.

Corriente, Federico (1977). A Grammatical Sketch of the Spanish Arabic Dialect Bundle. Madrid: Instituto Hispano-Árabe de Cultura. 
Cotter, William (2013). Dialect contact and change in Gaza City. MA dissertation, University of Essex, UK.

Cotter, William, \& Uri Horesh (2015). Social integration and dialect divergence in coastal Palestine. Journal of Sociolinguistics 19: 460-483.

Eckert, Penelope (1998). Age as a Sociolinguistic Variable. In Florian Coulmas (ed.), The Handbook of Sociolinguistics. Oxford: Blackwell. 151-167.

Eckert, Penelope, \& William Labov (2017). Phonetics, phonology and social meaning. Journal of Sociolinguistics 21:467-496.

Gal, Susan (1978). Peasant men can't get wives: Language change and sex roles in a bilingual community. Language in Society, 7: 1-16.

Hock, Hans Henrich (1986). Principles of historical linguistics. Berlin: Mouton de Guyter.

Hock, Hans Henrich and Brian D. Joseph. (2009). Language history, language change, and language relationship: An introduction to historical and comparative linguistics. 2nd revised edition. Berlin: Mouton de Gruyter.

Holes, Clive (1980). Phonological variation in Bahraini Arabic: The [j] and [y] allophones of /j/. Zeitschrift für arabische Linguistik 1: 72-89.

Holes, Clive (1987). Language variation and change in a modernising Arab state: The case of Bahrain (Vol. 7). London: Kegan Paul International.

Holes, Clive (1991). Kashkasha and the fronting and affrication of the velar stops revisited: A contribution to the historical phonology of the peninsular Arabic dialects. In Alan S. Kaye. Semitic studies in honor of Wolf Leslau on the occasion of 
his eighty-fifth birthday, November 14th, 1991. Wiesbaden, Harrassowitz. 652678.

Holes, Clive (2001). Dialect, culture, and society in Eastern Arabia. Leiden: Brill.

Horesh, Uri (2015). Structural change in Urban Palestinian Arabic induced by contact with Modern Hebrew. In: Aaron Butts (ed.). Semitic languages in contact. Leiden: Brill. 198-233.

Hussain, Abeer (2017). The sociolinguistic correlates of dialect contact and koineisation in Medini Arabic: Lenition and desyllabification. PhD thesis, University of Essex.

Ingham, Bruce (2009) The dialect of the Euphrates Bedouin: A fringe Mesopotamian dialect. In: Al-Wer, Enam and de Jong, Rudolf, (eds.). Arabic dialectology: in honour of Clive Holes on the occasion of his sixtieth birthday. Leiden: Brill. 99-108.

Johnson, Daniel Ezra (2009). Getting off the GoldVarb standard: Introducing Rbrul for mixed effects variable rule analysis. Language and Linguistics Compass 3: 359383.

Johnstone, Barbara, Jennifer Andrus and Andrew E. Danielson (2006). Mobility, indexicality, and the enregisterment of 'Pittsburghese'. Journal of English Linguistics, 34: 77-104.

Kaye, Alan S. (1997) Arabic Phonology. In Alan, S. Kaye (ed.). Phonologies of Asia and Africa. Winona Lake: Eisenbrauns. 187-204.

Labov, William (1963). The social motivation of a sound change. Word 19: 273-309. 
Labov, William (1990). The intersection of sex and social class in the course of linguistic change. Language Variation and Change, 2: 205-254.

Labov, William (2001). Principles of linguistic change: Social factors. (Vol. 2). Oxford: Blackwell.

Lass, Roger (1980). On Explaining Language Change. Cambridge: Cambridge University Press.

Levin, Aryeh (1994) A grammar of the Arabic dialect of Jerusalem. Jerusalem: The Hebrew University Magnes Press. [In Hebrew].

Levin, Aryeh (2009). 'Imāla. In Kees Versteegh et al. (eds.) Encyclopedia of Arabic Language and Linguistics. Leiden: Brill. 311-315.

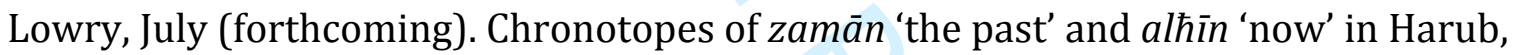
Saudi Arabia.

Messaoudi, Leila (2019) Variation and Koinéization in the Maghreb. In Enam Al-Wer and Uri Horesh (eds.). The Routledge Handbook of Arabic Sociolinguistics. London: Routledge. 203-213.

Milroy, James (1993). On the social origins of language change. In Charles Jones (ed.), Historical linguistics: Problems andpPerspectives. London: Longman. 215-236.

Owens, Jonathan (2001). Arabic sociolinguistics. Arabica 48: 419-469.

Owens, Jonathan (2006). A linguistic history of Arabic. Oxford: Oxford University Press. 
Owens, Jonathan (2013). Chapter 504 and modern Arabic dialectology: What are kaškaša and kaskasa, really? In Clive Holes and Rudolf de Jong (eds.). Ingham of Arabia: A collection of articles presented as a tribute to the career of Bruce Ingham. Leiden: Brill. 173-202.

Paul, Hermann (1880). Prinzipien der Sprachgeschichte. Halle: Max Niemeyer.

Sankoff, Gillian (2005). Cross-sectional and longitudinal studies in sociolinguistics. In Ulrich Ammon, Norbert Dittmar, Klaus J. Mattheier and Peter Trudgill (eds.). Sociolinguistics: An international handbook of the science of language and society, (Vol.1). Berlin: Mouton de Gruyter. 1003-1013.

Silverstein, Michael (2003). Indexical order and the dialectics of sociolinguistic life. Language \& Communication 23: 193-229.

Steinsholt, Anders (1962). Målbryting i hedrum. Oslo: Universitetsforlaget.

Taqi, Hanan (2010). Two ethnicities, three generations: Phonological variation and change in Kuwait. PhD thesis, University of Newcastle, UK.

Thomason, Sarah Grey and Terrence Kaufman (1988). Language contact, creolization, and genetic linguistics. Berkeley: University of California Press.

Trudgill, Peter (1986). Dialects in contact. Oxford: Blackwell.

Trudgill, Peter (2004). New-dialect Formation: The inevitability of colonial Englishes. Oxford: Oxford University Press.

Zaborski, Andrzej (2007). Jīm. In Kees Versteegh et al. (eds.). Encyclopedia of Arabic language and linguistics. Vol. 3. Leiden: Brill. 494-496. 
Weinreich, Uriel, William Labov and Marvin I. Herzog (1968). Empirical foundations for a theory of language change. In, Winfred P. Lehmann and Yakov Malkiel (eds.). Directions for historical linguistics. Austin: University of Texas Press. 95-195.

Woidich, Manfred and Liesbeth Zack (2009). The g/ğ-question in Egyptian Arabic revisited. In Enam Al-Wer and Rudolf de Jong (eds.). Arabic dialectology: In honour of Clive Holes on the occasion of his sixtieth birthday, 41-60. Leiden: Brill.

${ }^{1}$ Many of these studies appear in unpublished doctoral theses written by co-authors of this paper.

${ }^{2}$ This term was first coined by Steinsholt (1962) in Norwegian as språkmisjoncer. Trudgill (1986: 56-57) translates the relevant passage by Steinsholt as follows: 'The urban dialect spreads into Hedrum [in southern Norway] partly as a result of the influence of particular individuals living in different parts of the area. Such individuals - we can call them 'language missionaries' - may be village people who have been particularly heavily influenced by the urban dialect. The most important language missionaries are first the young girls who come home after living for a while in the town, and secondly the whalers'.

${ }^{3}$ But see Eckert (1998) for a discussion of age grading as a possible confound when relying on apparent time for such determinations.

${ }^{4}$ Carried out in Rbrul (Johnson 2009).

${ }^{5}$ In Al-Qouz's study, it was found that none of the traditional features were used by the younger Bahāanna in the school environment, which was attended by children of both groups.

${ }^{6}$ Indeed, Barkat-Defradas (2009: 678; but see Corriente 1977 for the original analysis) discusses vowel raising in Arabic and argues that it 'is often connected with the phenomenon 
of umlaut and defined as 'the inclination of [a] due to the umlauting influence of [i]' (Kaye 1997:198).' However, she qualifies this definition by contending, ' 'imāla should be regarded as an unconditioned process that applies to all [a] inside a word - unless they appear in the environment of any blocking segment (i.e. pharyngealized consonants) - as well as final [a] if such a phenomenon is attested in the dialect in question.' Barkat-Defradas's lemma on vowel raising, from which these quotes are taken, additionally offers useful acoustic correlates of this feature, which are beyond the scope of this article.

${ }^{7}$ As in our summary of Alaodini's results, a factor weight (FW) greater than 0.5 indicates a statistically significant favouring of the application of a phonological rule (in this case $a \rightarrow i$ ), based on a step-up-step-down multivariate analysis carried out with the statistical software package Rbrul (Johnson 2009).

8 'Palatalisation' and 'depalatalisation' are broad terms, which may include, inter alia, affrication and deaffrication. These are discussed in detail by Bhat (1978). The kind of palatalisation that results in the change of stops to affricates is considered by Bhat (1978: 56) a case of '[s]pirantization as distinct from fronting and raising'.

${ }^{9}$ This type of levelling out of marked features at early points of contact between speakers of different dialects in tabula rasa situations is called by Trudgill (2004) 'rudimentary levelling'.

${ }^{10}$ Najdi refers to a sub-type of Arabian Peninsula dialects. Varieties of Najdi are spoken nowadays not only in the province of Najd, in central Arabia, but also by several tribes in the Syrian Steppe and Jordan, as well as in the Gulf states.

${ }^{11}$ Jeddah is the capital of Hijaz, which generally corresponds to the western provinces of Saudi Arabia. 


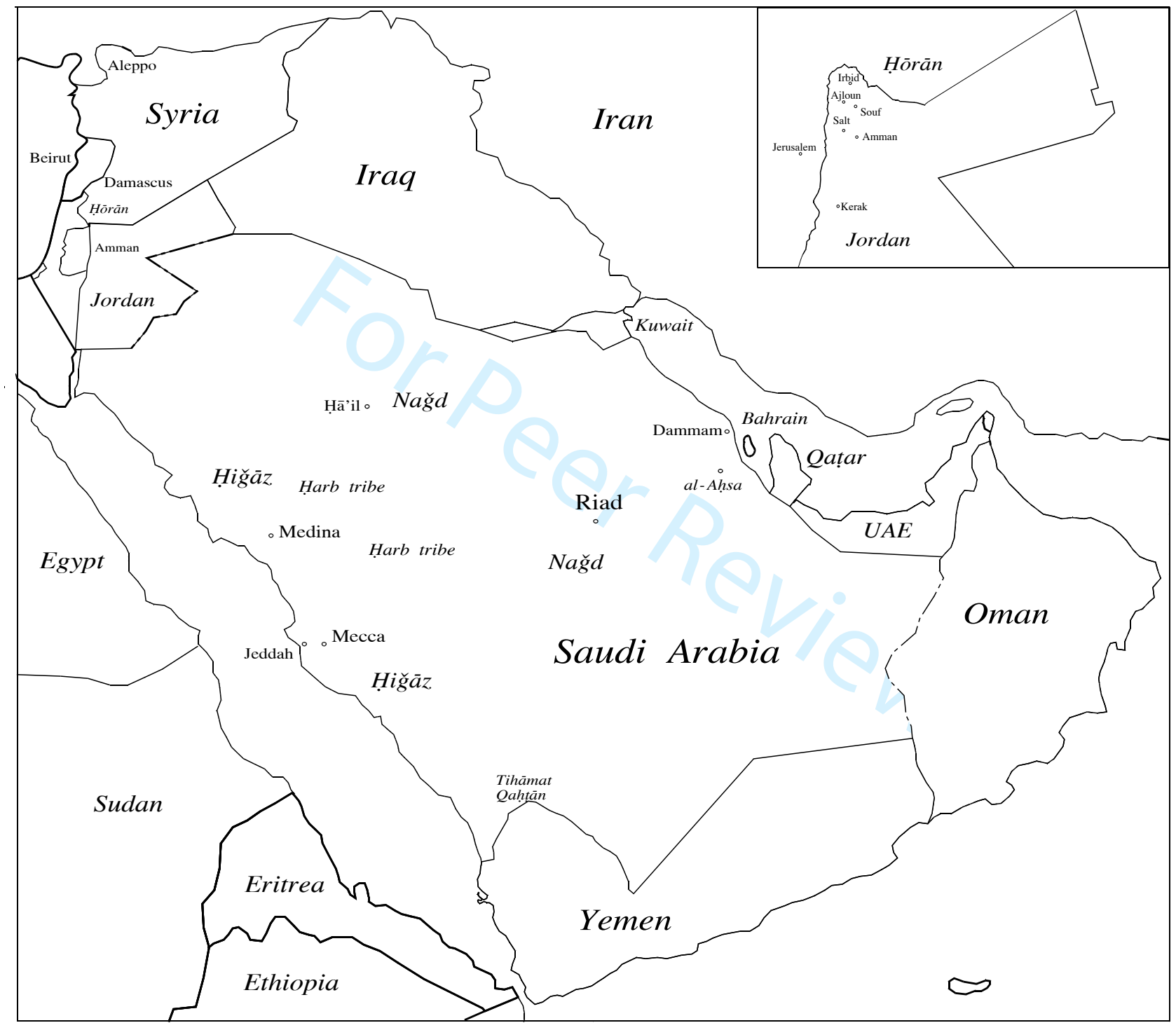




\begin{tabular}{|c|c|c|c|}
\hline Variable & Community & $\begin{array}{l}\text { Direction } \\
\text { of change }\end{array}$ & Social motivation \\
\hline \multirow{4}{*}{ (d) } & Jordan & $d 3>3$ & Traditional Jordanian $>$ Levantine koiné \\
\hline & Medina & $d 3>3$ & Traditional Medina $>$ Cosmopolitan Jeddah \\
\hline & $\begin{array}{l}\text { Al-Ahsa } \\
\text { Dammam }\end{array}$ & $\mathrm{j}>\mathrm{d} 3$ & Local traditional $>$ Pan-Saudi norm \\
\hline & Bahrain & $\mathrm{d} \mathrm{j} \sim \mathrm{j}>\mathrm{j}$ & Bahārna/`Arab distinction > General Gulf \\
\hline \multirow{2}{*}{$(\mathrm{AH})$} & Amman & $\mathrm{a} \sim \mathrm{e}>\mathrm{e} \sim \mathrm{a}$ & Traditional Jordanian [a] default $>$ Levantine $[\mathrm{e}]$ default \\
\hline & Ha’il & $\mathrm{e}>\mathrm{a}$ & Traditional Ha'il > Pan-Saudi norm \\
\hline \multirow{3}{*}{$(\mathrm{k})$} & Amman & $\mathrm{t}>\mathrm{k}$ & Traditional Jordanian $>$ Urban Levantine \\
\hline & Sūf & $\mathfrak{y}>\mathrm{k}$ & Traditional Jordanian > Urban (Amman) \\
\hline & Jeddah & $\begin{array}{c}\mathrm{ts}>\mathrm{k} \\
(\text { also ds }>\mathrm{g})\end{array}$ & Minority Najdi variant $>$ Majority Jeddah variant \\
\hline$\left(d^{\complement}\right)$ & Tihāmat Qahțān & $\mathrm{B}^{\mathrm{q}}>\mathrm{\partial}^{\mathrm{q}}$ & Merger due to contact with Pan-Saudi norms \\
\hline
\end{tabular}




\begin{tabular}{|l|l|l|}
\hline & $\%$ AFFRICATE in stem & $\%$ AFFRICATE in enclitic \\
\hline Jeddah & $6 \%$ & $22 \%$ \\
\hline Sūf & $11 \%$ & $70 \%$ \\
\hline
\end{tabular}

Table 2: percent affricate in stem vs enclitic in two dialects 


\begin{tabular}{|lllll|}
\hline Gender & Old & Young & Total & Tokens \\
Female & $16 \%$ & $69 \%$ & $45 \%$ & 196 \\
Male & $20 \%$ & $27 \%$ & $23 \%$ & 120 \\
Total & $18 \%$ & $55 \%$ & $37 \%$ & 316 \\
\hline
\end{tabular}

Table 3: $\left[{ }^{\S}\right]$, Cross-tabulation of age and gender 